\title{
Impact of Standing Water on the Existence of Several Species of Grasshoppers (Orthoptera) in the Rice Field Ecosystem
}

\author{
Ari Sugiarto \\ Email: sugiartoari13@gmail.com
}

\begin{abstract}
The formation of standing water in the rice field ecosystem in the rainy season is estimated to cause differences in the existence of several species of grasshoppers compared to the end of dry season. Research needs to be done on impact of standing water on the existence of several species of grasshoppers (Orthoptera) in the rice field ecosystem. This research was conducted from September to December 2018 by observing several species of gasshoppers in the rice field ecosystem at the end of the dry season and the rainy season. The results of the observations indicate a difference in the presence of several species of grasshoppers at the end of the dry season and the rainy season. This is because in the rainy season formed a standing water forms which causes the sinking of some vegetation to cause vegetation to grow into groups. This condition is estimated to cause grasshoppers to adaptation to changes so that there are differences in the presence of several species of grasshoppers at the end of dry season and rainy season.
\end{abstract}

Keywords: Dry Season, Grasshoppers, Rainy Season, Rice Field Ecosytem, Standing Water

\section{Introduction}

Grasshoppers (Orthoptera) are more common in the rice field ecosystem than in plantation ecosystems (Sugiarto, 2018). The pattern of distribution of grasshoppers in an ecosystem is one of them related to the availability of food in various types of vegetation (Almeida and Camara, 2008). The change in the dry season to the rainy season causes a plant transition in rice ecosystem (Heckman, 1979). In addition, the presence of standing water in the rice field ecosystem will limit the movement of grasshoppers, this is estimated to have an impact on the existence of several species of grasshoppers in the rice field ecosystem. According to Seino et al. (2013), grasshoppers have sensitivity to disturbances in an ecosystem. Research needs to be done on the impact of standing water in the rice field ecosystem on the presence of several species of grasshoppers.

\section{Research Methods}

This research was conducted from September to December 2018. The method of this research was carried out by observing several species of grasshoppers, namely Atractomorpha crenulata, Gesonula mundata, Oxya Hyla, Phlaeoba fumosa, and Xenocatantops humilis in the rice field ecosystem. According to Sugiarto (2018), Atractomorpha crenulata, Gesonula mundata, Oxya Hyla, Phlaeoba fumosa, and Xenocatantops humilis are species of grasshoppers that are easily found in the rice field ecosystem.

This observation is conducted at the end of the dry season (post-harvest) and the rainy season, this observation is conducted at the same location. According to Meteorology, Climatology and Geophysics Agency (2018), estimates of the beginning of the dry season in 2018/2019 in the territory of Indonesia generally begin in May and June 2018, while the rainy season starts in October to December 2018.

\section{Results and Discussion}

Observation of the existence of several species of grasshoppers at the end of the dry season found that the existence of Atractomorpha crenulata and Oxya Hyla at 
the edges to the middle of the rice fields. The existence of these two species of grasshoppers at the edge of the rice fields is not far from the lower edge. Phlaeoba fumosa and Xenocatantops humilis are located on the upper edge until they pass a little lower edge, but not until the middle of the rice fields. The existence of Gesonula mundata is only in the rice fields, not close to the bottom edge.

Atractomorpha crenulata and Oxya Hyla are species of grasshoppers which are more compared to Gesonula mundata in the rice field ecosystem, while Xenocatantops humilis is more compared to Phlaeoba fumosa at the edges. The depiction of the existence of grasshoppers at the end of the dry season in the rice field ecosystem can be seen in Figure 1.

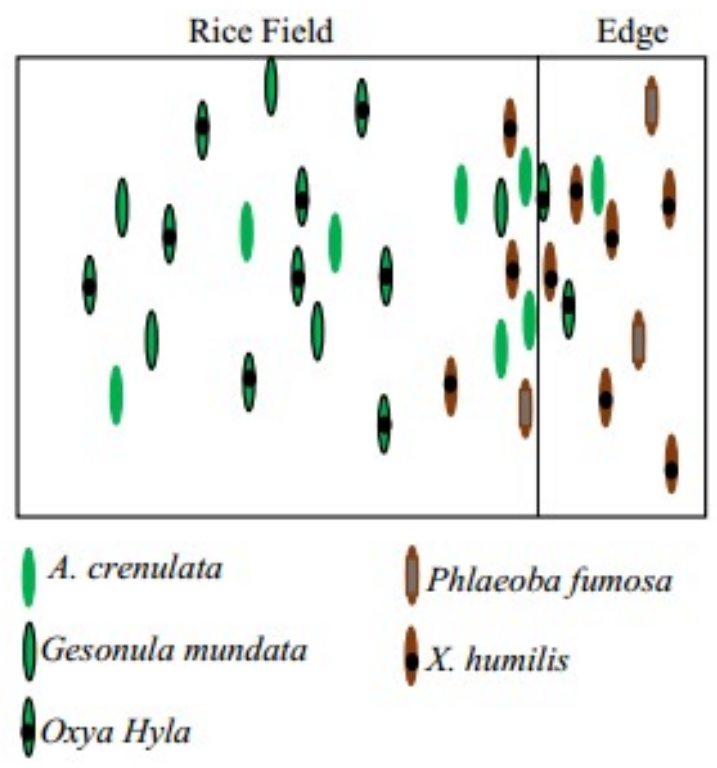

Figure 1. Depiction of the existence of several species of grasshoppers in the rice field ecosystem before the presence of standing water.

Observation in the rainy season, when the rice field ecosystems start to be flooded, the existence of Atractomorpha crenulata and Oxya Hyla are found at the lower edge to the middle of rice fields, while at the end of the dry season the existence of these two species of grasshoppers spread from the edge to the middle of rice fields. Phlaeoba fumosa and Xenocatantops humilis are the existence at the edges, while at the end of the dry season the presence of these two species of grasshopper from the upper edge extends beyond the lower edge. The existence of the Gesonula mundata is only in the middle of the rice fields, while at the end of the dry season its presence is also spread near the edges. The depiction of the existence of grasshoppers in the rainy season in the rice field ecosystem after of standing water can be seen in Figure 2.

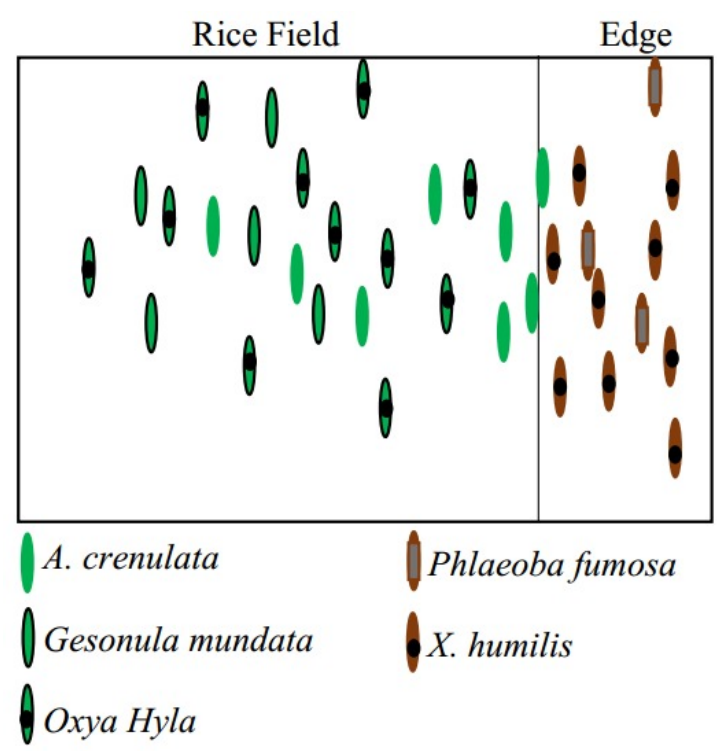

Figure 2. Depiction of the existence of several species of grasshoppers in the rice ecosystem after the presence of standing water.

There is not change in the number of grasshoppers in the rainy season compared to the end of the dry season. Atractomorpha crenulata and Oxya Hyla still dominate compared to other species of grasshoppers in rice fields, while at the edges of Xenocatantops humilis number the still dominate. Observation of some species of grasshoppers at the end of the dry season and the rainy season shows that there are differences in the presence of several species of grasshopper in the rice ecosystem, this is estimated to be an adaptation of grasshoppers to changes that occur in the rice field ecosystem. According 
to Seino et al. (2013), grasshoppers have sensitivity to disturbances in an ecosystem.

Plant vegetation at the end of the dry season is dominated by bushs and grasses. At the edges of the bush vegetation dominates over grass vegetation, while in the rice fields the grass vegetation dominates over bush vegetation. In the rainy season it is also found that bush vegetation dominates the edges and grass vegetation dominates the rice fields. The difference between dry season and rainy season vegetation is that the vegetation that grows at the end of the dry season is spread throughout the rice ecosystem, while the vegetation that grows in the rainy season is spread in groups. This can be caused by vegetation that grows at the end of the dry season drowning by standing water in the dry season which causes the vegetation to grow into groups. In addition, lotus, lily water, and other aquatic plants also begin to grow during the rainy season when before formed of standing water in the rice field ecosystem. According to Heckman (1979), plants that grow when the rice field ecosystem begins to be standing water such as Paspalum paspalodes, Echinochloa crus-galli, Cyperus iria, Cyperus polistachyos, and Fimbristylis littoralis.

\section{Conlusion}

Observation of the presence of several species of grasshoppers in the rice field ecosystem at the end of the dry season and the rainy season shows a difference in the presence of grasshoppers. This is because in the rainy season formed of standing water that causes the sinking of some vegetation to cause vegetation to grow into groups. This condition is estimated to cause grasshoppers to adaptation to changes so that there are differences in the presence of several species of grasshoppers at the end of the dry season and the rainy season.

\section{References}

Almeida, A.V and Camara, C.A.G. 2008. Distribution of Grasshoppers (Othoptera: Acridoidea) in The
Tapacurá Ecological Station (São Lourenço da Mata, PE / Brazil). Braz. J. Biol. 68(1): 2124.

Heckman, C.W. 1979. Rice Field Ecology in Northeastern Thailand. Springer Science + Business, B.V.

Meteorology, Climatology and Geophysics Agency. 2018. Forecast of the Rainy Season in 2018-2019 in Indonesia. (Online). https://www.bmkg.go.id/berita/ ?p=prakiraan-musim-hujantahun-2018-2019-diindonesia\&lang=ID\&s=detil.

Accessed on December 23, 2018.

Meteorology, Climatology and Geophysics Agency. 2018. Forecast of the Dry Season in 2018-2019 in Indonesia. (Online). https://www.bmkg.go.id/iklim/ prakiraanmusim.bmkg? $\mathrm{p}=11004 \& \operatorname{tag}=\mathrm{p}$ rakiraan-musim\&lang=ID.

Accessed on December 23, 2018.

Seino, R.A., Dongmo,T.I., Kekeunou, S., Chifon, R.N., and Manjeli, Y. An inventory of short horn grasshoppers in the Menoua Division, West Region of Cameroon. Agriculture and Biology Journal of North America. 4(3): 291-299.

Sugiarto, A. 2018. An Inventory of Grasshoppers (Orthoptera: Acrididae) in the Plantation and Rice Field Ecosystems of Serdang Menang Village, Sirah Pulau Padang Sub-district, Ogan Komering Ilir District. (Online).

https://osf.io/preprints/inarxiv/ 
hfxp9/. Accessed on Desember 24, 2018. 